\title{
Stimulation and inhibition of proliferation in the small intestinal crypts of the mouse after in vivo administration of growth factors
}

\author{
C S Potten, G Owen, D Hewitt, C A Chadwick, H Hendry, B I Lord, L B Woolford
}

Cancer Research Campaign Departments of Epithelial Biology, C S Potten

G Owen

D Hewitt

C A Chadwick

Experimental Radiation Oncology, J H Hendry

and Experimental

Haematology,

B I Lord

L B Woolford

Paterson Institute for Cancer Research, Christie Hospital NHS Trust, Manchester

Correspondence to: Professor C S Potten, Department of Epithelial Biology, Paterson Institute for Cancr Research. for Cancer Research, Christie Hospital NHS Trust, Wilmslow Road,

Accepted for publication 23 September 1994

\begin{abstract}
The effects of epidermal growth factor (EGF), transforming growth factor $\alpha$ (TGF $\alpha$ ), insulin-like growth factor (IGF) I and II, acidic fibroblast growth factor (FGF), tumour necrosis factor $\alpha$ (TNF $\alpha$ ), macrophage inhibitory protein $1 \alpha$ (MIP1 $\alpha$ ) (LD78), and TGF $\beta-1$ on cell proliferation in the crypts of the small intestine of mice were investigated. Various doses and dosing regimens were tested. Three in vivo assays were developed, in each case involving detailed cell positional analysis of methyl tritiated thymidine labelling and mitotic activity. These allowed deductions to be made about the regions of the crypt and hence regions of the proliferative hierarchy (stem cells versus dividing transit cells) that are affected by treatment with growth factors. The assays involved: (1) normal untreated mice (an assay most likely to be effective for detecting inhibitors); (2) mice shortly after whole body irradiation when compensatory proliferation has been endogenously triggered (another assay for inhibitory factors, possibly ones associated specifically with the regenerative process); and (3) mice at late times (96 hours) after irradiation in the regression phase after a proliferative overshoot (an assay designed to detect stimulators). Little effect was seen after treatment with acidic FGF, TNF $\alpha$, or MIP-1 $\alpha$ but EGF, IGF-I and II, and TGF $\alpha$ can all be seen to exert some stimulatory effects on labelling or mitosis. EGF and IGF-I stimulate both unirradiated mice and 96 hour recipients, while TGF $\alpha$ had a greater effect on the 96 hour animals. In all cases, multiple doses were used. TGF $\beta$-1 was an effective inhibitor of proliferation in unirradiated and early regenerating (18 hour) animals. EGF was the most effective of the stimulators, raising the levels of proliferation at all positions in the crypt, but particularly in the upper crypt. IGF-I also exerted its effect predominantly in the upper crypt, while TGF $\alpha$ raised proliferation at all cell positions. TGF $\beta-1$ tended to have its strongest inhibitory effects in the lower (stem cell) regions of the crypt.

(Gut 1995; 36: 864-873)
\end{abstract}

Keywords: small intestine, growth factors, cell kinetics, labelling index
The mechanism by which cell replacement is regulated in the gastrointestinal tract is poorly understood despite the facts that: (a) parts of the gastrointestinal tract represent one of the most rapidly proliferating tissue of the body, with a cell in each small intestinal crypt of the mouse entering mitosis every five minutes and each cell in the proliferative compartment dividing twice a day, and (b) these proliferative processes have been studied extensively for more than half a century using cell kinetic techniques. In the mouse, the small intestinal crypts contain about 150 cells with these proliferative characteristics, while the crypt as a whole contains about 250 cells. Cell replacement is achieved by cell hierarchies, or lineages, with relatively few (4-16) lineage ancestor cells (or stem cells) which give rise to 6 (for 4 stem cells) to 4 (for 16 stem cells) dividing transit generations respectively. ${ }^{1}$ Somewhat surprisingly, this tissue with its rapid turnover rarely develops spontaneous cancer. This fact alone justifies a detailed study of the regulatory mechanisms that afford such a protection against carcinogenic transformation. In contrast to the small intestine, the crypts in the large bowel contain more cells, each of which passes through the cell cycle somewhat more slowly than in the small intestine. This site, in contrast to the small intestine, develops cancer relatively frequently and these cancers generally have a poor prognosis.

A valuable feature of the crypt organisation in the gastrointestinal epithelium, with its high degree of polarity and rapid cell migration through the tissue, is the fact that the topographical position of cells within the crypt can be related to their position within the cellular hierarchies; such that in good longitudinal sections through the middle of a crypt, the cells lying along the side of the flask shaped structure (the so called crypt column) represent a linear array of cells with the most immature cells (the stem cells) located near the bottom of the column and cells of increasing maturity (increasing transit generation number) arranged in sequential order up the vertical column. Thus, by analysing the characteristics and behaviour of cells at each individual position, cells of different hierarchical status can be studied. In this way, the stem cell population can be studied by analysing the lowest cell position in the crypts of the mid colon and cells either over the first four to five positions (scattered among the differentiated Paneth cells) or those immediately 
above the Paneth cells in the small intestinal crypt. We believe that the most likely location of the stem cells in the small intestinal crypt is in fact at about the fourth position from the base of the crypt, which is a position equivalent to the average first non-Paneth cell. ${ }^{1-3}$

Over the years we have developed detailed quantitative analysis techniques for recording proliferation, differentiation, cell death, and other parameters on a cell position by cell position basis in longitudinal sections through crypts, and sophisticated computer programmes for analysing these data. ${ }^{4-6}$ The data are recorded directly on appropriately programmed $\mathrm{BBC}$ microcomputers adjacent to the microscopes. By analysing the frequency plots of the proliferative cells, changes induced by a variety of experimental conditions can be analysed.

Regulation of cell proliferation has previously been considered (with particular reference to haemopoietic tissue) to depend on the interaction of stimulatory and inhibitory growth factors. Cell proliferation in the intestinal epithelium is very susceptible to stress conditions but its well defined structure makes it amenable to analysis of induced change. We investigated a variety of stimulatory and inhibitory growth factors, administered repeatedly in vivo and the patterns of cell proliferation in the cells in crypt columns were subsequently analysed in longitudinal crypt sections, as described above.

Epidermal growth factor (EGF) and transforming growth factor $\alpha$ (TGF $\alpha$ ) are growth factors that have been shown to either have stimulatory effects in wound healing or have specific tissue expression or receptors in the gastrointestinal tract. ${ }^{7-20}$ Insulin-like growth factor 1 (IGF-1) $)^{21-24}$ and either the acidic or basic fibroblast growth factors (a and bFGFs) ${ }^{25}$ have also been implicated in proliferation regulation in the gut. For some cell systems, transforming growth factor $\beta$ (TGF $\beta$ ) is stimulatory but for many it is a potent inhibitor. It is, therefore, fairly promiscuous in its effects. Receptors or regulatory function have been indicated for TGF $\beta$ in the gastrointestinal tract. ${ }^{26-31}$ Macrophage inhibitory protein $1 \alpha$ (MIP-1 $\alpha)$, within the haemopoietic tissue, has been shown to be a specific inhibitor of stem cell proliferation. ${ }^{32}$ Little is known of its effects on stem cells of other tissues, but a recent report has shown effects on clonogenic epidermal keratinocyte proliferation in vitro. ${ }^{33}$ The present studies used these factors but were also part of a general growth factor screening programme in the gut.

EGF, IGF-1, and TGF $\alpha$ and $\beta$ all induced some changes in the patterns of proliferation when administered over a protracted period of time. However, aFGF, TNF $\alpha$, and MIP- $1 \alpha$ could not generally be shown to have any significant effects on proliferation when administered as multiple doses.

\section{Methods}

Male BDF1 mice bred at the Paterson Institute, were used when 10 to 12 weeks of age. The mice were housed under conventional conditions with controlled 12 hour light cycle (lights on at 0600 hours), temperature, and humidity. The mice had free access to food. They were injected intraperitoneally with the appropriate dose of growth factor dissolved in saline. MIP-1 $\alpha$ was injected intravenously in some experiments. Multiple injections were spaced either $1,3,4$, or 6 hours apart depending on the growth factor and the overall time scale of administration (results presented in graphical form here involve either 1 hour or 6 hour spacings). Animals were killed 1, 3, 6, or 9 hours after the last injection of growth factor (graphical data involve 1 and 9 hour sampling times). The number of injections varied from 1 to 13 . Forty minutes before killing, all animals were injected with $25 \mu \mathrm{Ci}(925 \mathrm{kBq}$, specific activity $6 \mathrm{Ci} / \mathrm{mmol}$ or $222 \mathrm{GBq} / \mathrm{mmol}$ ) of methyl tritiated thymidine $\left({ }^{3} \mathrm{HTdR}\right)$ administered in $0.1 \mathrm{ml}$ saline. The experiments were performed taking into account the circadian rhythm wherever possible. This was more difficult when multiple dosing was used. Identically handled animals were used for control (saline injected) and GF treated groups. The mice were approximately $25 \mathrm{~g}$ in weight.

\section{ASSAY SYSTEMS}

Three different types of recipient animals were used in these experiments. ${ }^{43}$ The first group comprised normal untreated animals and this was primarily an inhibitor assay. In these animals there is a rapid endogenous rate of proliferation in the small intestinal crypts and as such these animals are unlikely to be useful detectors of stimulators since the system is already proliferating rapidly. However, these animals may be useful detectors of inhibitory growth factors. A second inhibitor assay involved animals irradiated with a dose of 8 Gy of Caesium ${ }^{137}$ $\gamma$ rays (about $4.0 \mathrm{~Gy} / \mathrm{min}$ ) which were then selected for assay immediately, or shortly, after irradiation. At this time, regenerative proliferation in the crypts (including the stem cells) is stimulated as a consequence of the acute cell death and reproductive sterilisation induced by the radiation. This system also may be useful for assay of inhibitory factors and may in fact have greater sensitivity than the normal mice, or be susceptible to a different set of regeneration associated regulatory factors. Finally, in a simulator assay, a third test group of animals was prepared by irradiation with $8 \mathrm{~Gy}$ of $\gamma$ rays, but these animals were used at much later times after irradiation, generally 72 and 96 hours. During this time interval, the regenerative process has been completed and in fact from the point of view of cellularity there has been an 'overshoot' in crypt size. This overshoot results in a compensatory endogenous switching off of proliferation, during which phase stimulatory growth factors may be effective. (For more extensive descriptions of thèse assays $\operatorname{see}^{43435}$.) 
GROWTH FACTOR DOSES, SOURCES, AND

INJECTION PROTOCOLS

Recombinant human TGF $\beta-1$ was supplied by Oncogene Science (New York) and MIP-1 $\alpha$ was supplied by British Biotechnology Ltd (Cowley), in its human form, LD78. Both TGF $\beta-1$ and MIP-1 $\alpha$ were injected at 0900, 1500, 2100, and 0300 hours over a period of three days (a total of 13 injections). The doses used were $1.2 \mu \mathrm{g}$ and $15 \mu \mathrm{g} / \mathrm{mouse} /$ injection respectively (about 48 and $600 \mu \mathrm{g} / \mathrm{kg}$ ). EGF was obtained from various sources and was injected at a dose of $0.25 \mu \mathrm{g} /$ injection $(\sim 10 \mu \mathrm{g} / \mathrm{kg})$. IGF-1 and IGF-II were obtained from Boehringer (Mannheim) and were administered at a dose of $0.25 \mu \mathrm{g} /$ injection. TGF $\alpha$ was obtained from ICN/Flow (High Wycombe) and was injected at doses of $0 \cdot 1$, 0.25 , and $0.5 \mu \mathrm{g} /$ injection. TNF $\alpha$ and aFGF were both obtained from British Biotechnology Ltd and were given at a dose of $0.25 \mu \mathrm{g} /$ injection. All material was dissolved and administered in saline and control animals received the same injection protocols using only saline. Acidic FGF was used because some initial in vitro studies indicated that it was more effective at stimulating growth than basic FGF when tested on IEC cell lines. ${ }^{25}$ Basic FGF should also be analysed in vivo and this is in progress at the moment together with studies using KGF, HGF, and PDGF.

\section{HISTOLOGY}

The small intestine (ileum) and colon were removed from all animals and fixed in Carnoy's fixative for 20 to 30 minutes before storage in $70 \%$ ethanol. The results for the colonic samples are generally to be reported elsewhere. The ileal region of the small intestine was cut into 10 lengths of approximately $1 \mathrm{~cm}$ each (fewer for the colon) and these were bundled in $3 \mathrm{M}$ surgical tape as described elsewhere. ${ }^{36}$ These bundles of 10 pieces of ileum were embedded in paraffin and transverse sections $(3 \mu)$ were prepared. These were dewaxed, hydrated, and dipped in nuclear emulsion (Ilford K5) and autoradiographs were prepared as has been described in detail elsewhere. ${ }^{37}$ After development, the slides were stained with haematoxylin and eosin. Each bundle thus provides 10 cross sections randomised for position along the ileum.

\section{SCORING}

Each experimental group usually consisted of a maximum of four mice (two mice in a few groups) and each mouse provided 10 cross sections of small intestine embedded in tape. The cost of the growth factors for these in vivo studies limited the numbers of animals per group in some cases. The two to four bundles from the two to four mice were embedded together in a single block of paraffin and sectioned. Thus, each slide provides 20-40 ileal cross sections in a pattern on the slides which permits the identification of individual mice. From each mouse, 50 crypt columns (for four mice) or 100 crypt columns (for two mice) were selected from good longitudinal sections cut through the middle of crypts. These were commonly the two sides of 25 longitudinal crypt sections. Thus, 200 crypt columns were scored per group irrespective of the group size. Each crypt column, or half crypt section, was recorded as a separate entry into an appropriately programmed BBC microcomputer located adjacent to the microscope. the data were recorded on a cell position by cell position basis, starting with the cell judged to be at the midpoint at the base of the crypt. The computer programme recorded this basal central cell as cell position 1 and continued recording the cells up the side until the crypt-villus junction was reached, generally at about cell position 20.56 The presence of ${ }^{3} \mathrm{HTdR}$ labelling (three or more grains) and mitotic activity was recorded and the data are presented as labelling or mitotic indices (LI or MI). The slides were scored blind.

\section{DATA ANALYSIS}

The data for the 200 half-crypt sections from the two to four mice were pooled to give a frequency plot of the number of labelled cells at each cell position along the sides of the crypts. Mitotic activity was simultaneously recorded, and the data were handled and analysed in the same way. Thus, for each treatment group, frequency plots for labelling and for mitosis were obtained. The mitotic data were used to check that changes in labelling were not due to effects on thymidine metabolism (for example, pool changes) as well as providing a second separate index of proliferative changes. The frequency plots for the treated groups were subjected to a smoothing process and were compared with those obtained from control animals which had been injected with an equivalent volume of saline to that used for the growth factor injections. The treated frequency distribution could be subtracted from the control curve or vice versa to show the actual cells triggered or suppressed by the treatment and their location in the crypt (see below). Other statistical manipulations of the data are also available within the crypt software package we have developed. ${ }^{5} 6$

\section{STATISTICS}

When comparing two frequency plots, such as those presented here, a variety of statistical tests could be applied and are available within the framework of our crypts analysis programme. We have used one of these involving the differences between control and treated LI data. This is based on an extension of the median test. ${ }^{38}$ At each cell position the common median for all the animals of the groups to be compared was calculated by combining the groups. Then the individual values for each animal in the two groups were classified as being above, or not above, the median. These values are then cast on a two by two contingency table for each cell position and a standard $\chi^{2}$ test was applied to test for significance. Tables for adjacent positions can be 

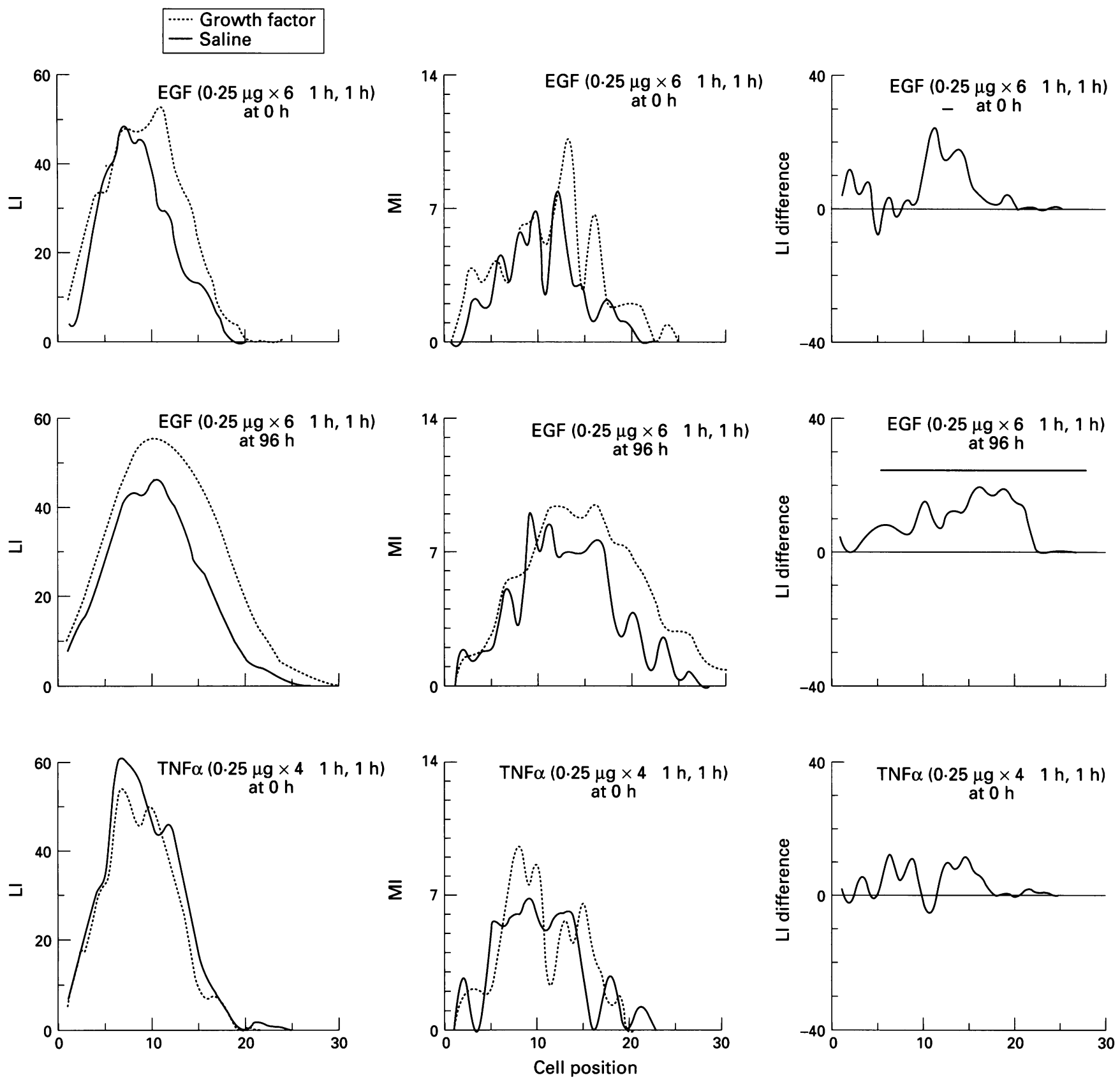

Figure 1: The data showing the stimulatory effect of 6 injections (1 hour apart) and analysis 1 hour later of epidermal growth factor (EGF) on unirradiated (upper three panels which are based on two animals, 200 half-crypts total for the treated and saline groups) and on mice 96 hours after irradiation (middle three panels, eight animals, 700 crypts for the EGF group, four animals, 300 crypts for saline). Labelling index (LI) (\%) changes are on the left and mitotic index $(M I)(\%)$ changes are in the middle. The right hand panel shows the application of the median test for significance on the difference plot for the LI data (that is, saline points subtracted from EGF treated points, see text). The cell positions over which significant effects ( $p<0.05$ ) are seen are shown by the thick horizontal bar. Similar analyses can be performed on the mitotic data (see Fig 4). The small area of significant effect in the upper right hand panel reflects the small number of animals studied. The lower three panels show examples where little or no effect was detected - in this case tumour necrosis factor $\alpha$ (TNF $\alpha$ ) treatment of unirradiated animals (4 injections 1 hour apart, 2 animals, 200 crypts for treated and saline groups). See Table I for further details. Treated groups (dotted line), saline groups (solid line).

determined to test for significance over a range of positions, in which case a reduced significance level $(0 \cdot 05 / \mathrm{n}$, where $\mathrm{n}$ is the number of cell positions tested, six in the present case) was used to correct for the large number of separate tests performed. An overall significance level of 0.05 has been used throughout. The cell positions over which significant changes are observed are shown on the figures by a horizontal bar. ${ }^{4}$

\section{Results}

One of the difficulties with this type of experiment is to know the dose, dose regimen, and time for assay after the administration of growth factors. Inevitably, the solution to this problem is to some extent empirical. We present here some examples of doses, dose regimens, and sampling times that showed an effect when compared with identically treated saline controls. The many cases where no effects were detected are not presented. It should be realised, however, that a negative result does not necessarily indicate that the growth factor in question is ineffective in the gut since the correct dose, dose regimen, and sampling time may not have been tested or the growth factor may not have been able to reach the relevant receptors at an appropriate concentration.

Various experimental protocols involving 
TABLE I Epidermal growth factor (EGF) data

\begin{tabular}{|c|c|c|c|c|c|c|c|}
\hline & \multicolumn{3}{|c|}{ Unirradiated mice } & \multicolumn{4}{|c|}{ Mice 96 h after 8 Gy } \\
\hline & $\begin{array}{l}\text { Saline } \\
\text { control }\end{array}$ & $\begin{array}{l}E G F(0 \cdot 25 \mu g) \\
\times 4,1 h \text { apart }^{\star}\end{array}$ & $\begin{array}{l}\text { Stimulation } \\
\text { factor }\end{array}$ & $\begin{array}{l}\text { Cell } \\
\text { position }\end{array}$ & $\begin{array}{l}\text { Saline } \\
\text { controlt }\end{array}$ & $\begin{array}{l}E G F(0 \cdot 25 \mu g) \\
\times 6,1 \text { h apart } \ddagger\end{array}$ & $\begin{array}{l}\text { Stimulation } \\
\text { factor }\end{array}$ \\
\hline 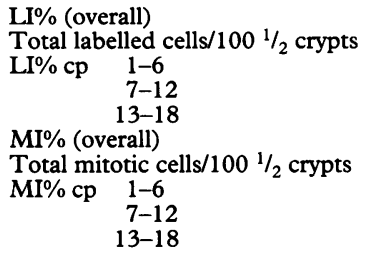 & $\begin{array}{c}22 \cdot 6 \\
439 \\
22 \cdot 8 \\
39 \cdot 5 \\
10 \cdot 8 \\
3 \cdot 1 \\
61 \\
1 \cdot 8 \\
5 \cdot 2 \\
2 \cdot 8\end{array}$ & $\begin{array}{c}26 \cdot 3 \\
575 \\
27 \cdot 0 \\
48 \cdot 5 \\
19 \cdot 2 \\
4 \cdot 3 \\
94 \\
2 \cdot 8 \\
5 \cdot 7 \\
5 \cdot 8\end{array}$ & $\begin{array}{l}1 \cdot 2 \\
1 \cdot 3 \\
1 \cdot 2 \\
1 \cdot 2 \\
1 \cdot 8 \\
1 \cdot 4 \\
1 \cdot 5 \\
1 \cdot 6 \\
1 \cdot 1 \\
2 \cdot 1\end{array}$ & $\begin{array}{c}1-8 \\
9-16 \\
17-24 \\
\\
1-8 \\
9-16 \\
17-24\end{array}$ & $\begin{array}{c}20 \cdot 5 \\
556 \\
24 \cdot 5 \\
36 \cdot 0 \\
6 \cdot 6 \\
4 \cdot 0 \\
109 \\
2 \cdot 2 \\
7 \cdot 7 \\
3 \cdot 1\end{array}$ & $\begin{array}{c}27 \cdot 5 \\
807 \\
30 \cdot 5 \\
50 \cdot 4 \\
17 \cdot 3 \\
5 \cdot 3 \\
156 \\
3 \cdot 0 \\
8 \cdot 9 \\
6 \cdot 0\end{array}$ & $\begin{array}{l}1 \cdot 3 \\
1.5 \\
1 \cdot 2 \\
1 \cdot 4 \\
2 \cdot 6 \\
1 \cdot 3 \\
1 \cdot 4 \\
1.4 \\
1 \cdot 2 \\
1.9\end{array}$ \\
\hline
\end{tabular}

$\mathrm{LI}=$ labelling index; $\mathrm{MI}=$ mitotic index

Cell position (cp) in crypt, approximate thirds of the crypt. NB The sizes of the crypts vary after irradiation.

*Two mice, $100 \mathrm{crypts} / \mathrm{mouse}(200 \mathrm{in}$ total); four mice, 300 crypts in total; $\ddagger$ eight mice, 700 crypts in total.

multiple injections were tested both on unirradiated animals and at the two different times after irradiation (that is, in the three assay systems). In one series of experiments, either four or six injections of growth factors were given with one hour intervals between the injections. Later experiments involved longer intervals between the injections (three or six hours). Altogether 66 different experimental situations were investigated each with its own saline control.

No significant changes in the pattern of proliferation could be detected after the administration of LD78 (MIP-1 $\alpha$ ), TNF $\alpha$, or acidic FGF in any of the experimental protocols (on unirradiated or irradiated recipients). There were occasional erratic cases of mild stimulation or mild inhibition but no consistent pattern could be observed. Four experiments were performed with each agent (two on unirradiated animals and two at 96 hours after irradiation). An example of a lack of effect is shown by one of the TNF $\alpha$ experiments in Figure 1 (four injections of $0.25 \mu \mathrm{g}$ one hour apart with analysis one hour later).

EGF

In 10 of 11 experiments, EGF showed evidence of stimulation of the small intestine when analysed by either the labelling or mitotic scores. Strong stimulation was observed when four injections of $0.25 \mu \mathrm{g} /$ mouse were given to normal unirradiated mice and the animals were assayed one hour after the last injection (see Fig 1 and Table I). EGF was also potently stimulatory when tested on mice 96 hours after irradiation (in the post-overshoot regression phase). Here, six injections $(0.25 \mu \mathrm{g})$ were given one hour apart, with analysis performed
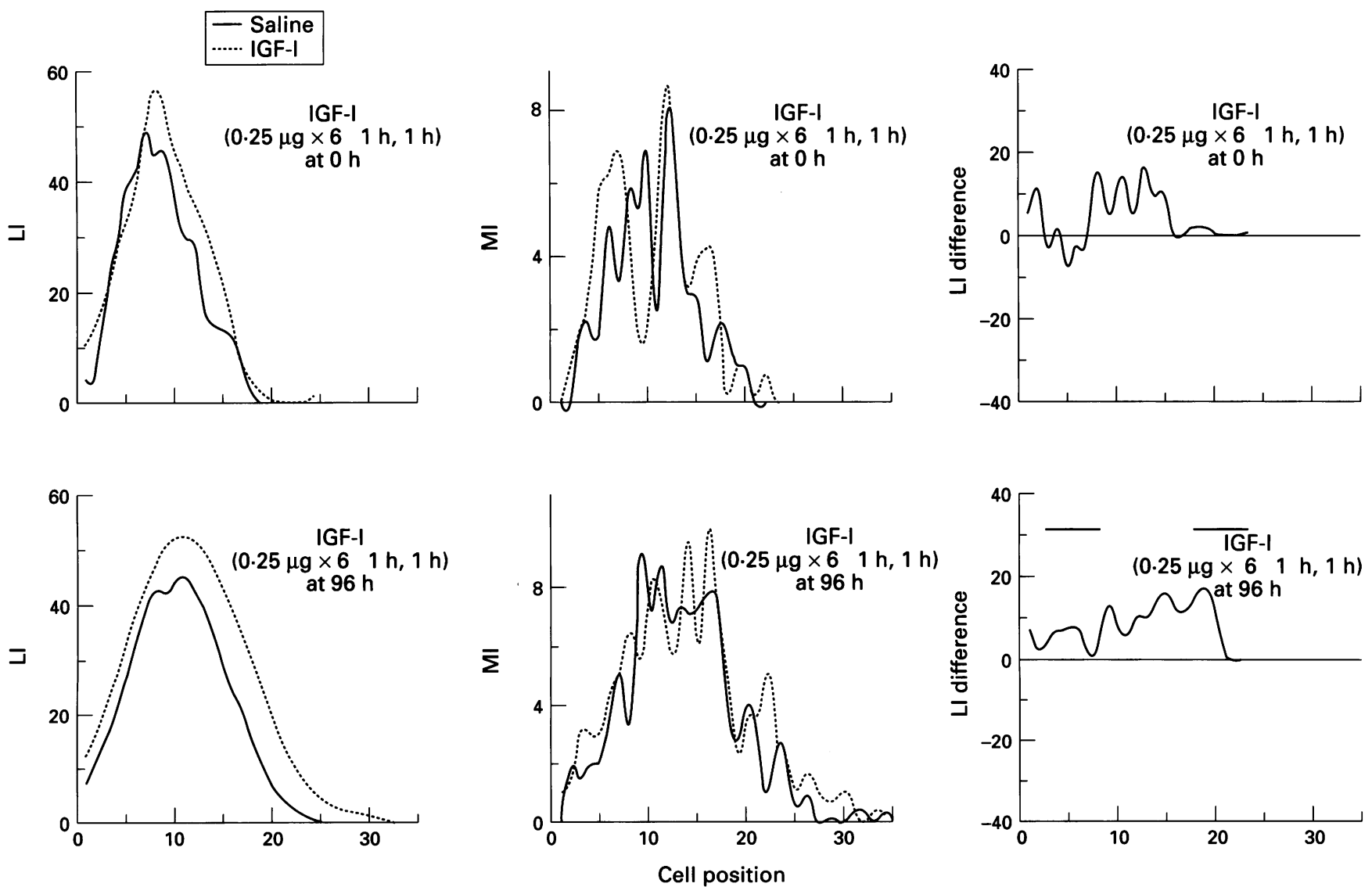

Figure 2: Data showing the stimulatory effects of 6 injections of insulin-like growth factor I (IGF-I) in unirradiated mice (upper panels) or animals 96 hours after irradiation (lower panels). For further details see Figure 1 and Table II. Significant effects were seen for the 96 hour treated groups. 
TABLE II Insulin-like growth factor (IGF) data

\begin{tabular}{|c|c|c|c|c|c|c|c|}
\hline & \multicolumn{3}{|c|}{ Unirradiated mice } & \multicolumn{4}{|c|}{ Mice 96 h after 8 Gy } \\
\hline & $\begin{array}{l}\text { Saline } \\
\text { control }^{\star}\end{array}$ & $\begin{array}{l}I G F-I(0 \cdot 25 \mu g) \\
\times 6,1 \text { hapart }^{\star}\end{array}$ & $\begin{array}{l}\text { Stimulation } \\
\text { factor }\end{array}$ & $\begin{array}{l}\text { Cell } \\
\text { position }\end{array}$ & $\begin{array}{l}\text { Saline } \\
\text { controlt }\end{array}$ & $\begin{array}{l}I G F-I(0 \cdot 25 \mu g) \\
\times 6,1 \text { hapart } \neq\end{array}$ & $\begin{array}{l}\text { Stimulation } \\
\text { factor }\end{array}$ \\
\hline $\begin{array}{l}\text { LI\% (overall) } \\
\text { Total labelled cells } / 1001 / 2 \text { crypts } \\
\begin{array}{ll}\text { LI\% cp } 1-6 \\
7-12 \\
13-18\end{array} \\
\begin{array}{l}\text { MI\% (overall) } \\
\text { Total mitotic cells } / 1001 / 2 \text { crypts } \\
\text { MI\% cp } 1-6 \\
7-12 \\
13-18\end{array}\end{array}$ & $\begin{array}{c}22 \cdot 6 \\
439 \\
22 \cdot 8 \\
39 \cdot 5 \\
10 \cdot 8 \\
3 \cdot 1 \\
61 \\
1 \cdot 8 \\
5 \cdot 2 \\
2 \cdot 8\end{array}$ & $\begin{array}{c}25 \cdot 9 \\
532 \\
23 \cdot 5 \\
47 \cdot 0 \\
17 \cdot 5 \\
3 \cdot 5 \\
72 \\
3 \cdot 0 \\
5 \cdot 0 \\
3 \cdot 5\end{array}$ & $\begin{array}{l}1 \cdot 1 \\
1 \cdot 2 \\
1 \cdot 0 \\
1 \cdot 2 \\
1 \cdot 6 \\
1 \cdot 1 \\
1 \cdot 2 \\
1 \cdot 7 \\
1 \cdot 0 \\
1 \cdot 2\end{array}$ & $\begin{array}{c}1-8 \\
9-16 \\
17-24 \\
\\
1-8 \\
9-12 \\
17-24\end{array}$ & $\begin{array}{c}20 \cdot 5 \\
556 \\
24 \cdot 5 \\
36 \cdot 0 \\
6 \cdot 6 \\
4 \cdot 0 \\
109 \\
2 \cdot 2 \\
7 \cdot 7 \\
3 \cdot 1\end{array}$ & $\begin{array}{c}28 \cdot 0 \\
786 \\
30 \cdot 8 \\
49 \cdot 0 \\
18 \cdot 0 \\
4 \cdot 5 \\
127 \\
3 \cdot 6 \\
7 \cdot 4 \\
3 \cdot 8\end{array}$ & $\begin{array}{l}1 \cdot 4 \\
1 \cdot 4 \\
1 \cdot 3 \\
1 \cdot 4 \\
2 \cdot 7 \\
1 \cdot 1 \\
1 \cdot 2 \\
1 \cdot 6 \\
1 \cdot 0 \\
1 \cdot 2\end{array}$ \\
\hline
\end{tabular}

$\mathrm{LI}=$ labelling index; $\mathrm{MI}=$ mitotic index. Cell position (cp) in crypt, see Table $\mathrm{I}$ for details.

${ }^{\star}$ Four mice, 300 crypts in total; $\neq$ two mice, 200 crypts in total.

one hour after the last injection (Fig 1 and Table I). The stimulation in both cases is seen in both the LI and MI, and is strongest in the upper regions of the crypt - that is, in the dividing transit population.

IFG-I AND II

Out of a total of nine experiments (different regimens) eight showed evidence of stimulation by IGF-I in the small intestine but the levels of stimulation were generally somewhat lower than those experienced with EGF. On one experiment ( 11 injections six hours apart begun shortly after irradiation) there was some indication of an inhibitory effect on mitosis. However, moderate stimulation of both the LI and $\mathrm{MI}$ in the upper regions of the crypt were observed when $0.25 \mu \mathrm{g}$ was administered six times, one hour apart to unirradiated animals and the analysis was performed one hour later (see Fig 2 and Table II).

Moderate stimulation was also seen when IGF-1 was administered to mice 96 hours after irradiation (Fig 2, Table II). Both the LI and MI were stimulated at all levels in the crypt that is, a generalised stimulation at all cell positions. IGF-II was tested in three experiments on 96 hours post-irradiation mice and was clearly stimulatory to about the same extent as IGF-1 in two experiments when given six or nine times $(0.25 \mu \mathrm{g})$ one hour apart (data not shown).

TGF $\alpha$

In eight of 11 experiments, TGF $\alpha$ showed signs of stimulating the small intestinal crypts. In six of seven experiments where TGF $\alpha$ was given to animals 96 hours after irradiation, good to moderate stimulation was observed for
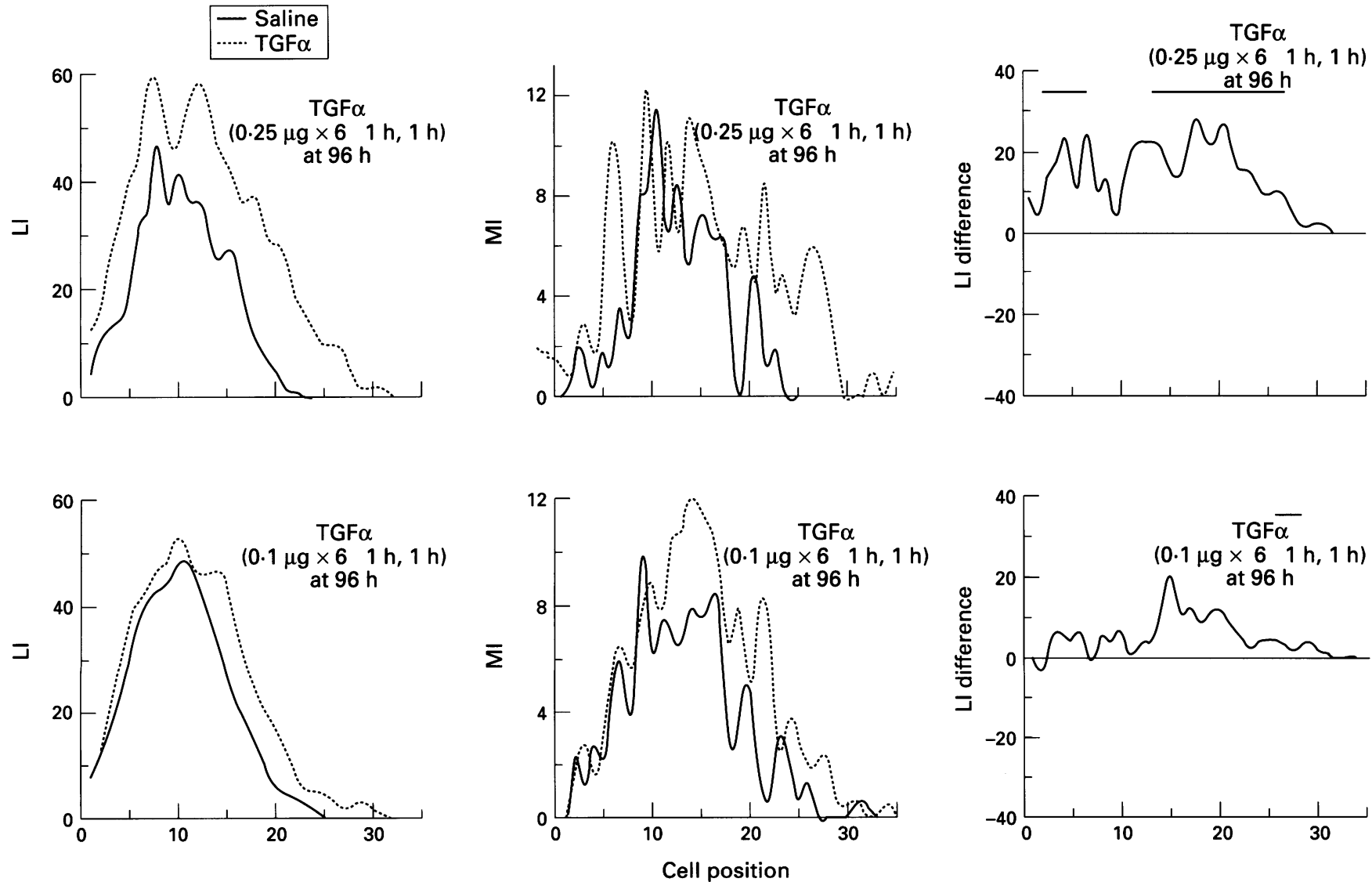

Figure 3: Data showing the stimulatory effects of 6 injections of transforming growth factor $\alpha$ (TGF $\alpha$ ) in mice 96 hours after irradiation. Upper panels are $0.25 \mu \mathrm{g}$ per injection, lower panels $0.10 \mu \mathrm{g} /$ injection. For further details see Figure 1 and Table III. 
TABLE III Transforming growth factor $\alpha(T G F \alpha)$ data

\begin{tabular}{|c|c|c|c|c|c|c|c|}
\hline & \multicolumn{3}{|c|}{$T G F \alpha(0.25 \mu g) 96 h$ after $8 G y$} & \multicolumn{4}{|c|}{$T G F \alpha(0.1 \mu g) 96 h$ after $8 G y$} \\
\hline & $\begin{array}{l}\text { Saline } \\
\text { control }\end{array}$ & $\begin{array}{l}\times 6, \\
1 \text { h apart }\end{array}$ & $\begin{array}{l}\text { Stimulation } \\
\text { factor }\end{array}$ & $\begin{array}{l}\text { Cell } \\
\text { position }\end{array}$ & $\begin{array}{l}\text { Saline } \\
\text { control }\end{array}$ & $\begin{array}{l}\times 6 \\
1 \text { h apart }\end{array}$ & $\begin{array}{l}\text { Simulation } \\
\text { factor }\end{array}$ \\
\hline 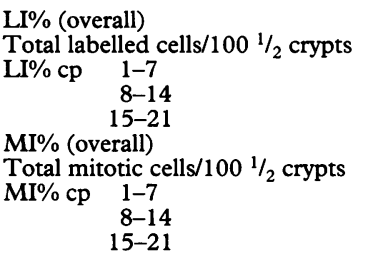 & $\begin{array}{c}18 \cdot 5 \\
479 \\
18 \cdot 0 \\
37 \cdot 0 \\
13 \cdot 3 \\
96 \\
3 \cdot 7 \\
1 \cdot 4 \\
7 \cdot 1 \\
4 \cdot 7\end{array}$ & $\begin{array}{c}28 \cdot 8 \\
917 \\
32 \cdot 7 \\
52 \cdot 3 \\
34 \cdot 7 \\
176 \\
5 \cdot 5 \\
4 \cdot 0 \\
7 \cdot 9 \\
6 \cdot 9\end{array}$ & $\begin{array}{l}1 \cdot 6 \\
1.9 \\
1 \cdot 8 \\
1 \cdot 4 \\
2 \cdot 6 \\
1.8 \\
1.5 \\
2.9 \\
1 \cdot 1 \\
1.5\end{array}$ & $\begin{array}{c}1-8 \\
9-16 \\
17-24 \\
\\
1-8 \\
9-16 \\
17-24\end{array}$ & $\begin{array}{c}21 \cdot 5 \\
594 \\
26 \cdot 9 \\
39 \cdot 1 \\
8 \cdot 1 \\
4 \cdot 2 \\
115 \\
2 \cdot 9 \\
7 \cdot 6 \\
3 \cdot 4\end{array}$ & $\begin{array}{c}27 \cdot 4 \\
759 \\
29 \cdot 9 \\
46 \cdot 5 \\
16 \cdot 0 \\
6 \cdot 1 \\
168 \\
3 \cdot 4 \\
10 \cdot 0 \\
6 \cdot 2\end{array}$ & $\begin{array}{l}1 \cdot 3 \\
1 \cdot 3 \\
1 \cdot 1 \\
1 \cdot 2 \\
2 \cdot 0 \\
1 \cdot 5 \\
1 \cdot 5 \\
1 \cdot 2 \\
1 \cdot 3 \\
1 \cdot 8\end{array}$ \\
\hline
\end{tabular}

$\mathrm{LI}=$ labelling index; $\mathrm{MI}=$ mitotic index. Cell position (cp) in crypt, see Table $\mathrm{I}$ for details.

^Two mice, 200 crypts in total for all groups.

both the $\mathrm{LI}$ and $\mathrm{MI}$ at all cell positions (six injections of $0.25 \mu \mathrm{g}$ or $0.1 \mu \mathrm{g}$ one hour apart with analysis one hour later) (see Fig 3 and Table III). However, generally little (two of four experiments), or no effect, or even some mild inhibition, was observed when TGF $\alpha$ was given as a series of injections $(4,6$, or 11$)$ of $0.25 \mu \mathrm{g}$ one hour or six hours apart to unirra- diated mice or very early after irradiation $(0.5$ hours).

TGF $\beta-1$

Altogether 20 experiments were performed with TGF $\beta-1$, in 18 of which there was some evidence of mild or good inhibition of
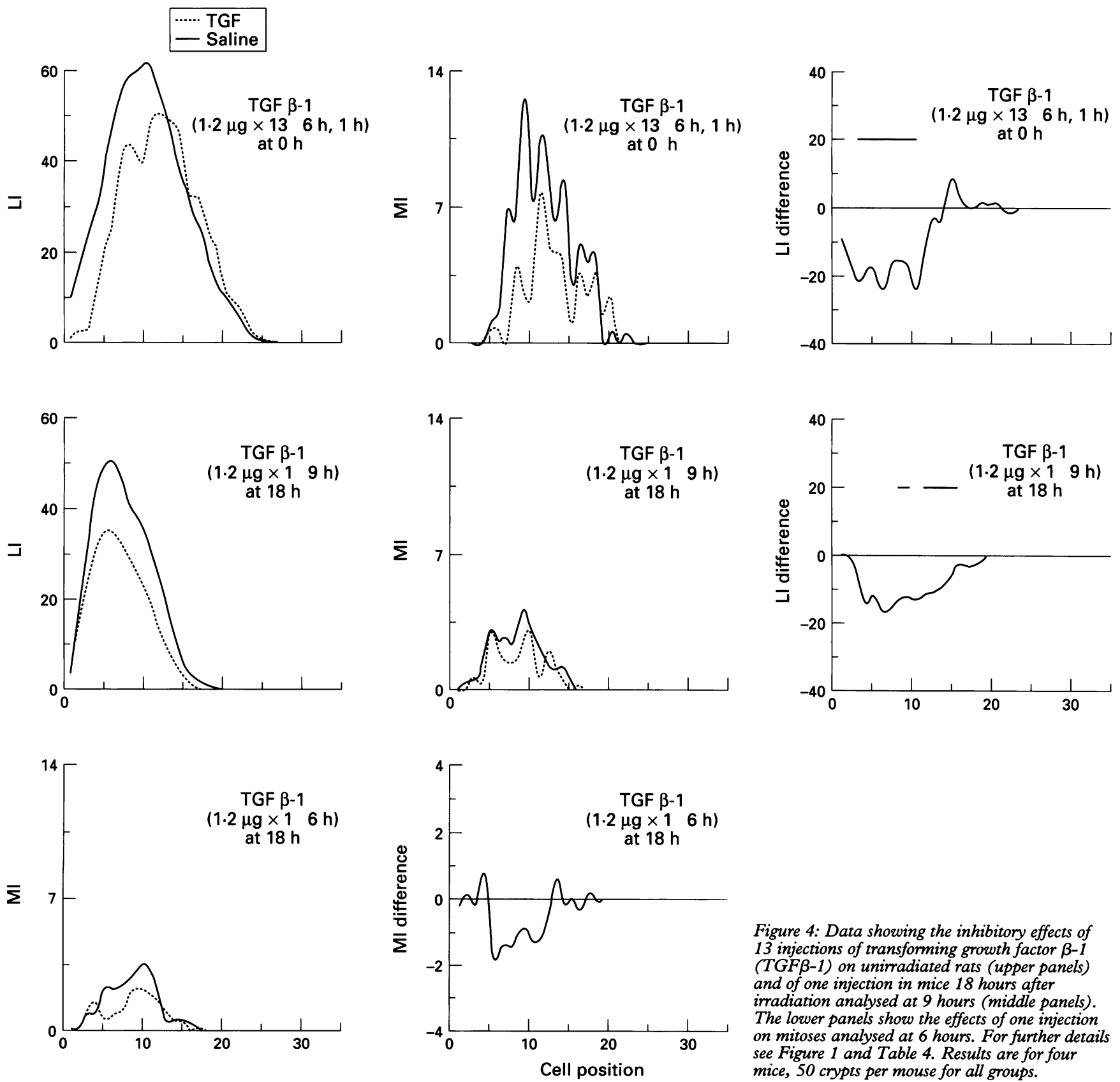

Figure 4: Data showing the inhibitory effects of 13 injections of transforming growth factor $\beta-1$ (TGF $\beta-1$ ) on unirradiated rats (upper panels) and of one injection in mice 18 hours after irradiation analysed at 9 hours (middle panels). The lower panels show the effects of one injection on mitoses analysed at 6 hours. For further details see Figure 1 and Table 4. Results are for four mice, 50 crypts per mouse for all groups. 
TABLE IV Transforming growth factor $\beta$ (TGF $\beta)$ data

\begin{tabular}{|c|c|c|c|c|c|c|c|c|c|c|c|}
\hline & \multicolumn{3}{|c|}{ Unirradiated mice } & \multicolumn{4}{|c|}{ Mice $18 \mathrm{~h}$ after $8 G y$} & \multicolumn{4}{|c|}{ Mice $18 \mathrm{~h}$ after $8 \mathrm{~Gy}$} \\
\hline & $\begin{array}{l}\text { Saline } \\
\text { control }\end{array}$ & $\begin{array}{l}T G F \beta(1 \cdot 2 \mu g) \\
\times 13,1 \text { h apart }\end{array}$ & $\begin{array}{l}\text { Inhibition } \\
\text { factor }\end{array}$ & $\begin{array}{l}\text { Cell } \\
\text { position }\end{array}$ & $\begin{array}{l}\text { Saline } \\
\text { control }\end{array}$ & $\begin{array}{l}T G F \beta(1 \cdot 2 \mu g) \\
\times 1,9 h\end{array}$ & $\begin{array}{l}\text { Inhibition } \\
\text { factor }\end{array}$ & $\begin{array}{l}\text { Cell } \\
\text { position }\end{array}$ & $\begin{array}{l}\text { Saline } \\
\text { control }\end{array}$ & $\begin{array}{l}T G F \beta(1 \cdot 2 \mu g) \\
\times 1,6 h\end{array}$ & $\begin{array}{l}\text { Inhibition } \\
\text { factor }\end{array}$ \\
\hline LI\% (overall) & $35 \cdot 8$ & $27 \cdot 9$ & $1 \cdot 3$ & & $21 \cdot 9$ & $15 \cdot 0$ & 1.5 & & $21 \cdot 0$ & $21 \cdot 5$ & $1 \cdot 0$ \\
\hline $\begin{array}{l}\text { Total labelled cells/ } \\
1001 / 2 \text { crypts }\end{array}$ & & & & & & & & & & & \\
\hline $\mathrm{LI} \% \mathrm{cp}_{1-8}$ & $\begin{array}{l}770 \\
35.1\end{array}$ & 615 & $1 \cdot 3$ & & 460 & 312 & 1.5 & & 440 & 451 & $1 \cdot 0$ \\
\hline $9-16$ & $49 \cdot 1$ & 43.6 & $\begin{array}{l}2 \cdot 0 \\
1 \cdot 1\end{array}$ & $\begin{array}{l}1-6 \\
7-12\end{array}$ & $\begin{array}{l}31 \cdot 0 \\
37 \cdot 2\end{array}$ & $24 \cdot 6$ & $\begin{array}{l}1 \cdot 3 \\
1.5\end{array}$ & $\begin{array}{l}1-6 \\
7-12\end{array}$ & $\begin{array}{l}29 \cdot 8 \\
38 \cdot 1\end{array}$ & $\begin{array}{l}27 \cdot 9 \\
40 \cdot 2\end{array}$ & $\begin{array}{l}1 \cdot 1 \\
0.9\end{array}$ \\
\hline $17-24$ & $11 \cdot 8$ & $15 \cdot 3$ & 0.8 & $13-18$ & $7 \cdot 8$ & 3.5 & $2 \cdot 2$ & $13-18$ & $5 \cdot 3$ & $7 \cdot 0$ & 0.8 \\
\hline $\mathrm{MI} \%$ (overall) & $4 \cdot 1$ & $2 \cdot 2$ & 1.9 & & $1 \cdot 3$ & 0.9 & $1 \cdot 4$ & & $1 \cdot 2$ & 0.8 & 1.5 \\
\hline Total mitotic cells/ & & & & & & & & & & & \\
\hline $1001 / 2$ crypts & 89 & 48 & $1 \cdot 8$ & & 27 & 19 & $1 \cdot 4$ & & 26 & 17 & 1.5 \\
\hline $\mathrm{MI} \% \mathrm{cp} \quad 1-8$ & $2 \cdot 1$ & 0.7 & $3 \cdot 0$ & $1-6$ & $1 \cdot 3$ & $1 \cdot 0$ & $1 \cdot 3$ & $1-6$ & $1 \cdot 1$ & 0.7 & 1.6 \\
\hline $9-16$ & $7 \cdot 8$ & $4 \cdot 0$ & $2 \cdot 0$ & $7-12$ & $2 \cdot 7$ & $1 \cdot 8$ & 1.5 & $7-12$ & $2 \cdot 8$ & $1 \cdot 7$ & $1 \cdot 6$ \\
\hline $17-24$ & $1 \cdot 3$ & $1 \cdot 3$ & $1 \cdot 0$ & $13-18$ & $0 \cdot 5$ & $0 \cdot 3$ & $1 \cdot 7$ & $13-18$ & $0 \cdot 4$ & 0.5 & $0 \cdot 8$ \\
\hline
\end{tabular}

$\mathrm{LI}=$ labelling index; $\mathrm{MI}=$ mitotic index. Cell position $(\mathrm{cp})$ in crypt, see Table $\mathrm{I}$

${ }^{\star}$ Four mice, 200 crypts in total for all groups.

proliferation in the crypts of the small intestine. There was a generally more pronounced inhibition of mitosis than labelling but protracted exposure of unirradiated animals (13 injections of $1.2 \mu \mathrm{g}$ six hours apart and analysis one hour later) resulted in a strong general inhibition of mitosis and a moderate inhibition of labelling (see Fig 4 and Table IV). The effects were particularly pronounced in the lower crypt - that is, in the stem cell and early transit populations. There were occasional signs of stimulation of labelling in the upper crypt under conditions where mitosis was inhibited throughout the crypt.

In one experiment, a single injection of $1 \cdot 2 \mu \mathrm{g}$ TGF $\beta$ was given to animals 18 hours after irradiation (beginning active regeneration), Here, inhibition of mitotic activity began to be evident one to three hours after administration. This mitotic inhibition was pronounced at six hours and had diminished slightly by nine hours at which time there was a pronounced inhibition of labelling (see Fig 4 and Table IV).

The data on the colon will be presented elsewhere but broadly speaking they show similar trends. EGF is stimulatory to the colon particularly after multiple injections to 96 hours post-irradiation samples. Interestingly, TGF $\beta$ seems to show stimulation at certain times after a single injection, and inhibition at other times, in both the colon and ileum. IGF-1 seems to inhibit the colon in unirradiated animals but stimulates the 96 hour recipients when given as four injections one hour apart and in the colon there is some indication that $M I P-1 \alpha$ is inhibitory while $\mathrm{TNF} \alpha$ is stimulatory. These data, however, await further repetition and a full scale analysis.

Of the data presented here on the ileum the following conclusions can be drawn:

(1) There is little obvious influence on proliferation of MIP-1 $\alpha, \mathrm{TNF} \alpha$, and aFGF, using the doses and injection protocols studied.

(2) EGF is clearly stimulatory when given over a protracted period of time to unirradiated mice or 96 hours after irradiation.

(3) IGF-I and probably IGF-II are stimulatory in some cases when given to unirradiated mice or 96 hours after irradiation but the effects are less pronounced and less reproducible then with EGF.

(4) $\mathrm{TGF} \alpha$ has only mild stimulatory effects on unirradiated animals but can cause moderate stimulation in animals 96 hours after irradiation.

(5) TGF $\beta-1$ is a fairly effective inhibitor of proliferation of both unirradiated and early post-irradiation animals which are undergoing active regenerative proliferation. Protracted exposures are most effective but there are indications that the time of analysis after exposure to TGF $\beta$ may be an important element with good inhibition being noted nine hours after a single injection while early times may show evidence of some stimulation.

It was noticeable that $T G F \beta-1$, particularly in the extended injection protocol, had effects on the general wellbeing of the mice. Their activity was depressed and they lost weight $(\sim 25 \%)$. On autopsy, the small intestine showed indications of haemorrhage. MIP-1 $\alpha$ in the same protracted injection protocol had no effect on either the wellbeing of the animals or the condition of the small intestine.

\section{Discussion}

These experiments were designed partly to identify the conditions that are most appropriate for studying the effects of stimulatory or inhibitory growth factors, in vivo, on cell proliferation in the intestinal crypts. Thus, postirradiation overshoot conditions where cell proliferation is declining have been used to study potential stimulators and normal and radiation-stimulated conditions were used for studies involving inhibitors.

EGF has already been implicated in wound repair in the gastrointestinal tract. ${ }^{18-20} \mathrm{TGF} \alpha$ is known to have a stimulatory effect on some biological system, ${ }^{8}$ while IGF-I has been implicated in proliferation of the gut. ${ }^{24}$ In contrast, TGF $\beta$ has widespread inhibitory (or in some cases, stimulatory) effects in many tissues. ${ }^{39} 40$ MIP-1 $\alpha$ (LD78) is inhibitory within the bone marrow, at least for stem cell proliferation. ${ }^{32} 41-43$

These results suggest that EGF and IGF may have some role as stimulatory factors in both normal animals and animals recovering after irradiation when present at high levels for a protracted period of time (Figs 1 and 2). This is greatest in the post-recovery animals where EGF, and more significantly $\mathrm{TGF} \alpha$ (Fig 3), extend both the range of proliferation further 
along the crypt into the normally quiescent zones, possibly as a consequence of increasing the number of transit generations, and in the stem cell regions, perhaps indicating that the more primitive cells, relaxing after a period of induced proliferation, are more readily restimulated than normal. Stimulation of the stem cells into more rapid cycles alone would also increase the levels of proliferation in the upper region of the crypt by increasing the input into the dividing transit population. EGF and TGF $\alpha$ may therefore be involved in some way in the controls of tissue regeneration and may be of some potential value in the enhancement of these processes if administered at an appropriate time and over an appropriate time scale.

Based on a limited series of experiments, MIP-1 $\alpha$ (LD78) clearly has no obvious antiproliferative effects on cells in the crypts of the small intestine either under normal or stimulated conditions. Neither does it have any overt toxic effects on the general wellbeing of the animal over the term of the experiments and using a dosage regimen in excess of that known to have effects in vivo on haemopoietic stem cell proliferation. ${ }^{43}$

By contrast, TGF $\beta-1$ potently inhibited proliferation over half to three quarters of the lower region of the crypts in normal animals (Fig 4). However, haemorrhage into the gut was apparent and the wellbeing of the animals deteriorated. Gross destruction of the gut's cellular architecture after a further two days treatment with similar dose regimens of TGF $\beta-1$ were reported by Migdalska et $a l^{27}$ and a recent report by Oberhammer ${ }^{44}$ presented in vivo evidence of increased hepatocyte (apoptotic) death. Loss of proliferative activity with TGF $\beta-1$ may therefore be the result of poor microenvironmental conditions and it is difficult to escape the conclusion that protracted TGF $\beta-1$ in vivo may present serious toxicity problems. However, there are indications that the time of analysis may be important for detecting the effects of agents such as TGF $\beta$ and more detailed temporal studies are needed before a full assessment of the potential value of TGF $\beta$ is made. Preliminary studies suggest that proliferation may be affected at certain times after even a single dose of TGF $\beta$ which would not involve the complicated side effects associated with protracted exposure. These preliminary studies also suggest that both inhibition and stimulation may be seen at various times after a single exposure to TGF $\beta$. This may be the consequence of a synchronisation effect of cells leaving an arrested state once the effect of the inhibition has worn off. Alternatively, it may be a reflection of the variability in TGF $\beta$ responses in various tissues and conditions.

Some of the effects seen may be the result of simultaneous effects on the duration of mitosis and the $S$ phase. In which case, the data suggest that the growth factors in question have some action on these stages of the cell cycle. Alternatively, the growth factors may be acting on $G_{1}$ or $G_{2}$, or both, in a more conventional fashion. In either case, the consequences would be expected to be seen as changes in the cell cycle duration. It is noteworthy that the changes often exhibit cell positional (cell hierarchy) dependence suggesting that the effects have some specificity for certain cells and are not non-specific proliferating cell responses.

None of these agents result in complete stimulation or inhibition - that is, they do not seem to be acting in a manner that would be expected of primary growth initiators or terminators, that is, primary switches for 'on' or 'off' of proliferation, but IGF, EGF, TGF $\alpha$, and TGF $\beta$ may play important modulatory roles in small intestinal crypt cell proliferation, particularly after injury.

This work has been supported by the Cancer Research Campaign. We are grateful to British Biotechnology Ltd and Oncogene Science (New York) for their donations of growth factors. We are grateful to the Histology laboratory and Laboratory 19 for their help with various aspects of the preparatory work.

1 Potten CS, Loeffler ML. Stem cells: attributes, cycles, spirals, uncertainties and pitfalls: lessons for and from the crypt. Development 1990; 110: 1001-19.

2 Potten CS, Hendry JH. Stem cells in murine small intestine. In: Potten CS, ed. Stem cells: their identification and characterisation. Edinburgh: Churchill Livingstone, 1983: 155-99.

3 Wright NA, Alison M. The biology of epithelial cell population. Oxford: The Clarendon Press, 1984.

4 Potten CS, Owen G, Roberts SA. The temporal and spatial changes in cell proliferation within the irradiated crypts of the murine small intestine. Int $\mathcal{f}$ Radiat Biol 1990; 57: 185-99.

Potten CS, Kellett M, Rew D, Wilson G. The in vivo measurement of proliferation in normal human colorectal mucosa using bromodeoxyuridine. Gut 1992; 33: 71-8.
6 Li YQ, Fan C, O'Connor PJ, Winton D, Potten CS. Target cells for the cytotoxic effects of carcinogens in the murine small bowel. Carcinogenesis 1992; 13: 361-8.

7 Blay J, Brown KD. Epidermal growth factor promotes the chemotactic migration of cultured rat intestinal epithelial cells. F Cell Physiol 1985; 124: 107-12.

8 Burgess AW. Epidermal growth factor and transforming growth factor $\alpha . B r M e d$ Bull 1989; 45: 410-24.

9 Cathridge SA, Elder JB. Transforming growth factor $\alpha$ and EGF levels in normal human gastrointestinal mucosa.

Br F Cancer 1990; 60: 657-60.
10 Conteas CN, Nandi Mujumdar AP. The effects of gastrin, epidermal growth factor, and somatostatin on DNA synthesis is a small intestinal crypt cell line (IEC-6). Proc Soc Exp Biol NY 1986; 184: 307-11.

11 Derynck R. Transforming growth factor alpha. Cell 1988; 54: 593-5.

12 Dyduch A. Proliferation effects of epidermal growth factor on the intestinal epithelium of mice. Morphol Embryol (Bucur) 1990; 36: 141-3.

13 Goodlad RA, Lee CY, Wright NA. Cell proliferation in the small intestine and colon of intravenously fed rats: effects small intestine and colon of intravenously fed rats: effects
of urogastrone-EGF. Cell Proliferation 1992; 25: 393-404.

14 Malo C, Menard D. Influence of epidermal growth factor on the development of suckling mouse intestinal mucosa. Gastroenterology 1982; 83: 28-35.

15 Sizeland A, Bol S, Burgess AW. The action of epidermal growth factor (EGF) is limited to specific phases of the cell cycle in an EGF dependent colonic cell line. Growth Factors 1991; 4: 129-43.

16 Murthy U, Ario A, Grieg A, Grieg RG. Expression of TGF $\alpha / E G F$ and TGF- $\beta$ receptors in human colon carcinoma of cell lines. Int $\mathcal{f}$ Cancer 1989; 44: 110-5.

17 Pérez-Tomás R, Culleré X, Dias C. Immunohistochemical localisation of transforming growth factor $\alpha$ in the

developing rat colon. Gastroenterology 1993; 104: 789-95.
8 Thompson JS, Saxena SK, Sharp JG. Effect of urogastrone Thompson JS, Saxena SK, Sharp JG. Effect of urogastrone
on intestinal regeneration is dose-dependent. Cell Tissue on intestinal regeneration
Kinet 1988; 21: 182-93.

19 Thompson JS, Saxena SK, Sharp JG. Effect of the duration of infusion of urogastrone on intestinal regeneration in rabbits. Cell Tissue Kinet 1989; 22: 303-11.

20 Wright NA, Pike C, Elia G. Induction of a novel epidermal growth factor-secreting cell lineage by mucosal ulceration in human gastrointestinal stem cells. Nature 1990; 343: $82-5$.

21 Guo Y-S, Narayan S, Yallampalli C, Singh P. Characterisation of insulinlike growth factor I receptors in human colon cancer. Gastroenterology 1992; 102: 1101-8.
22 Heinz-Erian P, Kessler U, Funk B, Gais P, Kiess W. Identification and in situ localisation of the insulin-like growth factor-II/mannose-6-phosphate (IGF-II/M6P) growth factor-II/mannose-6-phosphate (IGF-II/M6P) receptor in the rat gastrointestinal tract: comparison with

the IGF-I receptor. Endocrinology 1991; 129: ???-??
23 Park JH, Vanderhoof JA, Blackwood D, MacDonald RG. Characterisation of type I and type II insulin-like growth factor receptor in an intestinal epithelial cell line.
Endocrinology 1990; 126: 2998-3005. 
24 Whitehead RH, Nice EC, Lloyd CJ, James R, Burgess AW. Detection of colonic growth factors using a human colonic carcinoma cell (LIM1215). Int 7 Cancer 1990; 46: 858-63.

25 Cove FL, Evans GS. The use of an intestinal epithelial cell line as a biological assay system for growth factor activity. Biochem Soc Trans 1992; 20: 175S.

26 Kurokowa M, Lynch K, Podolsky DK. Effects of growth factors on an intestinal epithelial cell line: Transforming growth factor $\beta$ inhibits proliferation and stimulates differentiation. Biochem Biophys Res Commun 1987; 142: 775-82. Migdalska A, Molineux G, Demuynck H, Evans GS,
Ruscetti F, Dexter TM. Growth inhibitory effects of transforming growth factor- $\beta 1$ in vivo. Growth Factors 1991; 4: 239-45.

28 Avery A, Paraskeva C, Hall P, Flanders KC, Sporn M, Moorghen M. TGF- $\beta$ expression in the human colon: differential immunostaining along crypt epithelium. $\mathrm{Br} f$ Cancer 1993; 68: 137-9.

29 Barnard JA, Beauchamp RD, Coffey RJ, Moses HL. Regulation of intestinal epithelial cell growth by transforming growth factor type $\beta$. Proc Natl Acad Sci USA 1989; 86: 1578-82.

30 Chakbabarty S, Fan D, Varani J. Modulation of differentiation and proliferation in human colon carcinoma cells by transforming growth factor $\beta 1$ and $\beta 2 . B r \mathcal{F}$ Cancer 1990; 46: 493-9.

31 Lahm H, Odartchenko N. Role of transforming growth factor $\beta$ in colorectal cancer. Growth Factors 1993; 9: 1-9.

32 Graham GJ, Wright EG, Hewick R, Wolpe SD, Wilkie NM, Donaldson D, et al. Identification and characterisation of an inhibitor of haemopoietic stem cell proliferation. Nature 1990; 344: 442-4.

33 Parkinson EK, Graham GJ, Banbosies P, Burns JE, Heuffler C, Plumb $M$, et al. Haemopoietic stem cell inhibitor (SCI/MIP-1 $\alpha$ ) also inhibits clonogenic epidermal keratinocyte proliferation. F Invest Dermatol 1993; 101: 113-7.
34 Potten CS, Chadwick CA. Small intestinal growth regulatory factors extracted by simple diffusion from intact irradiated intestine and tested in vivo. Growth Factors 1994; 10: 63-75.

35 Potten CS. A comprehensive study of the radiobiological response of the murine (BDF1) small intestine. Int $f$ Radiat Biol 1990; 58: 925-73.

36 Potten CS, Hendry JH. The microcolony assay in mouse small intestine. In: Potten CS, Hendry JH, eds. Cell clones: manual of mammalian cell techniques. Edinburgh: Churchill-Livingstone, 1985: 50-60.

37 Potten CS, Chwalinski S, Swindell R, Palmer M. The spatial organisation of the hierarchical proliferative cells of the small intestine into clusters of 'synchronised' cells. Cell Tissue Kinet 1982; 15: 351-70.

38 Siegel S. Non-parametric statistics for behavioural sciences. McGraw Hill, New York, 1956.

39 Roberts AB, Sporn MB. Physiological actions and clinical applications of transforming growth factor- $\beta$ (TGF- $\beta$ ). applications of transforming

40 Sporn MB, Roberts AB. Transforming growth factor- $\beta$ : recent progress and new challenges. $\mathcal{f}$ Cell Biol 1992; 119: 1017-21.

41 Lord BI, Morri KJ, Alright EG, Lajtha LG. An inhibitor of stem cell proliferation in normal bone marrow? $\mathrm{Br} \mathcal{F}$ Haematol 1976; 34: 441-5.

42 Tejero C, Testa NG, Lord BI. The cellular specificity of haemopoietic stem cell regulators. Br $\mathcal{F}$ Cancer $1984 ;$ 50: 335-41.

43 Lord BI, Dexter TM, Clements JM, Hunter MG, Gearing $\mathrm{AJH}$. Macrophage inflammatory protein protects multipotent hemopoietic cells for the cytotoxic effects of potent hemopoietic cells for the cytotoxic
hydroxyurea in vivo. Blood 1992; 79: 2605-9.

44 Oberhammer F, Pavelka M, Parchio A, Bursch W, SchulteHermann R. Induction of apoptosis in cultured hepatocytes and in the regressing liver by transforming growth factor $\beta 1$. Cell Proliferation 1992; 25: A471. 